\title{
Effect of Inclusion of Moringa oliefera Leaf Meal on the Growth Performance, Nutrient Digestibility and Carcass Characteristics of Deccani Lambs
}

S.M. Bhokre1, N. Rajanna², A. Sarat Chandra², D. Nagalakshmi ${ }^{3}$, D.B.V. Ramana ${ }^{4}$, M. Shasi Kumar ${ }^{5}$

10.18805/ajdfr.DR-1686

\begin{abstract}
Background: Moringa (Moringa oleifera) is a highly valued plant grown in tropical and subtropical countries. Moringa has a high amount of crude protein, a well-balanced amino acid profile, vitamins and minerals and fewer quantities of antinutritive factors. Methods: Eighteen growing Deccani lambs of uniform body weight $(14.22 \pm 1.5 \mathrm{~kg})$ and age were randomly allotted to three treatment groups viz., 100 per cent groundnut cake (T1), $75 \%$ groundnut cake+ $25 \%$ Moringa oliefera leaf meal (T2) and $50 \%$ groundnut cake+ $50 \%$ M. oliefera leaf meal (T3) as a protein source in the concentrate mixture. The experiment was conducted for 90 days.

Result: No significant difference was found in the fortnightly body weights of the lambs from $1^{\text {st }}$ to $6^{\text {th }}$ fortnights among three dietary groups. Total weight gain and Average Daily gain (ADG) were significant $(P<0.01)$ among the treatment groups whereas DMI (kg/day), per $100 \mathrm{~kg}$ and FCR was non-significant. The digestibility coefficients $(\%)$ of all nutrients were non-significant $(P>0.05)$ except the NFE. Pre-slaughter weight, empty body weight, hot carcass weights and dressing percent on pre-slaughter weight and empty body weight were comparable among the three groups. Results of the present study indicated that inclusion of $25 \%$ Moringa oleifera leaf meal in concentrate mixture proved to be superior and improved the growth performance, digestibility of nutrients and carcass traits without any adverse effects on experimental lambs.
\end{abstract}

Key words: Carcass characteristics, Deccani lambs, Growth performance, Moringa oleifera leaf meal, Nutrient digestibility.

\section{INTRODUCTION}

The availability of feed and fodder remains a major area of concern; there is a gap between its demand and supply in the country. The utilization of fodder trees and shrubs could be a potential strategy for increasing the quality and availability of feeds for resource-limited livestock farmers during the dry season. In recent years, there has been increased research on alternative protein sources from forage trees and shrubs that can be fed to sheep. Attention has been given to the use of moringa leaf meal (MLM) as a protein source and feed component in animal production (Sarwatt et al., 2002; Gerbregiorgis and Negesse, 2011and Moyo et al., 2012).

Moringa (Moringa oleifera) belongs to the Moringaceae family and is locally popular as drumstick tree or Miracle tree. Moringa is a perennial plant that can be harvested several times in one growing season, can be easily established in a field, has the good copping ability and has good potential for forage production reaching $12 \mathrm{~m}$ height at maturity yielding up to120 tonnes/ha/year, when planted very densely for use as forage (Makkar and Becker, 1997). Moringa as a leaf fodder has been tried as a protein source for livestock (Makker and Becker, 1997; Sarwatt et al., 2002) and observed to increase animal performance in many parts of the world. Moringa leaves have negligible content of tannins and no trypsin and amylase inhibitors and cyanogenic glucosides (Makkar and Becker, 1997). Almost
1Department of Livestock Production Management, KNP College of Veterinary and Animal Science, Maharashtra Animal and Fishery Sciences University, Shirwal, Satara, Pune-411 002, Maharastra, India.

2Department of Livestock Production Management, College of Veterinary Science, P.V. Narasimha Rao Telangana Veterinary University, Rajendranagar, Hyderabad-500 030, Telangana, India. ${ }^{3}$ Department of Animal Nutrition, College of Veterinary Science, P.V. Narasimha Rao Telangana Veterinary University, Rajendranagar, Hyderabad-500 030, Telangana, India.

${ }^{4}$ Department of Livestock Production Management, ICAR-Central Research Institute for Dryland Agriculture, Santoshnagar, Hyderabad500 030, Telangana, India.

${ }^{5}$ College of Dairy Technology, P.V. Narasimha Rao Telangana Veterinary University, Kamareddy-503 111, Telangana, India.

Corresponding Author: N. Rajanna, Department of LPM, College of Veterinary Science, P.V. Narasimha Rao Telangana Veterinary University, Rajendranagar, Hyderabad-500 030, Telangana, India. Email: neeradiraj@gmail.com

How to cite this article: Bhokre, S.M., Rajanna, N., Chandra, A.S., Nagalakshmi, D., Ramana, D.B.V. and Kumar, M.S. (2021). Effect of Inclusion of Moringa Oliefera Leaf Meal on the Growth Performance, Nutrient Digestibility and Carcass Characteristics of Deccani Lambs. Asian Journal of Dairy and Food Research. DOI: 10.18805/ajdfr.DR-1686.

Submitted: 16-04-2021 Accepted: 16-06-2021 Online: 17-09-2021 
Effect of Inclusion of Moringa oliefera Leaf Meal on the Growth Performance, Nutrient Digestibility and Carcass...

every part of the moringa tree, viz. fruit, flower, seed, bark, root and gum is a rich repository of proteins, vitamins and minerals including potassium, calcium, phosphorous, iron, folic acid as well as b-carotene (Amee Ravani et al., 2017). The present study was planned to study the growth performance, nutrient digestibility and carcass characteristics by the inclusion of dried Moringa oleifera leaf meal at a different level by replacing the GNC in the concentrate mixture of Deccani sheep.

\section{MATERIALS AND MeTHOdS}

The experiment on the inclusion of Moringa (Moringa oleifera) leaf meal on growth performance of growing Deccani sheep was conducted at Livestock Farm Complex (ILFC), College of Veterinary Science, Rajendranagar, Hyderabad during the year 2020. Eighteen growing Deccani sheep of uniform body weight $(14.19 \pm 1.5 \mathrm{~kg}$ ) and age (4 to 8 months) were randomly allotted to three treatment groups with six lambs in each group $(6 \times 3)$ in a completely randomized design. Three experimental diets were prepared viz., T1 (control without Moringa), T2 (75\% groundnut cake+ $25 \%$ inclusion of Moringa oliefera leaf meal) and T3 (50\% groundnut cake+ $50 \%$ inclusion of Moringa oliefera leaf meal) as a protein source in the concentrate mixture and offered @ $1 \%$ of body weight along with ad libitum green fodder.

All the lambs in the experiment were provided with a floor space of $1 \mathrm{~m} 2$ / lamb in the covered area with an asbestos roof. The experimental lambs were ear-tagged for proper recording of the data. All the lambs were dewormed with Albendazole @ $10 \mathrm{mg} / \mathrm{kg}$ body weight before the start of the experiment and once in the middle of the trail in both systems of management.

Chaffed Paragrass was offered adlibitum in the morning and evening for 90 days to meet the nutrient requirements of the lambs in an intensive system. Leftover feed and fodder, if any, was recorded the next day morning at 24 hourly intervals to calculate total dry matter consumption per day. Clean, wholesome and fresh drinking water was made available to each animal in water troughs throughout the experimental period.

The body weights of lambs were weighed by using an electronic digital balance at the fortnightly interval before offering feed and water in the morning throughout the experiment period. At the end of the growth trial, a sevenday digestibility trial was conducted on all lambs by keeping them in a completely randomized design (CRD) to assess the nutrient utilization of experimental diets.

The animals were kept in clean, well-aired individual metabolic cages with feeding and watering arrangement. During the collection period of seven days, daily feed consumption, leftover feed as well as faeces voided were recorded. Faeces were collected using faecal bags harnessed to the lambs. Representative samples of three experimental diets and green fodder were collected daily during the collection period before offering to animals and kept for dry matter estimation and pooled for seven days.
The faeces voided during $24 \mathrm{hrs}$ were collected and weighed daily for 7 days. For dry matter determination, aliquots of $1 / 10^{\text {th }}$ of daily faeces were taken from each animal in previously weighed Petri dishes and dried overnight in a hot air oven at $100 \pm 5^{\circ} \mathrm{C}$. For further chemical analysis, faecal materials were dried, ground through a $1 \mathrm{~mm}$ screen in a Wiley mill and preserved in airtight bottles. The proximate analysis of feeds was performed as per the procedures described by AOAC (2005). Fiber fractions in feeds were analyzed as per the method described by Van Soest et al. (1991).

The representative animals were slaughtered by 'Halal' methodology after 18 hours of starving. The live weights before slaughter were recorded. Stripping, legging, dressing and evisceration were performed by adopting the standard procedures described by Gerrand (1964). The data of the present study were analyzed as per the method of Snedecor and Cochran (1994).

\section{RESULTS AND DISCUSSION}

\section{Growth performance}

\section{Fortnightly body weights}

The fortnightly body weight changes of growing Deccani lambs in an intensive farming system are presented in Table 1. A perusal of the table reveals there was no significant difference in the fortnightly body weights of the lambs from 1st to 6th fortnight among three dietary groups. However, there was a linear increase in body weights in all three treatment groups. Relatively higher body weight was observed in Moringa-based diets (T2 and T3 groups) and lowest in control (T1 group) throughout the experiment. The numerically higher values in the group supplemented with moringa leaf meal show that it could contribute towards better livestock performance in terms of body weight changes and high yield of good-quality products as it contains an appreciable level of essential nutrients. The results of the present study are in concurrence with the findings of Damor et al. (2017), Syed Ali (2017) and Yosuf et al. (2018) who reported non-significant body changes in goats. In contrast to the present findings, Tono et al. (2014) and Sultana et al. (2015) found a significant gain in body weight of goats fed on diets with different levels of inclusion of Moringa oleifera leaves.

\section{Total weight gain}

Significantly $(P<0.01)$ highest weight gain was observed in T2 group lambs than T1 lambs. However, there was no significant difference between T1 and T3 groups and the T2 and T3 groups. This could be due to the positive effect of Moringa on intake, digestibility and nitrogen balance in T2 as compared to T3. The present results are similar to the findings of Sultana et al. (2015) and Damor et al. (2017) who reported a significant increase in total body weight gain in goats fed with different levels of Moringa olifera leaves. Dissimilar results were reported by Babeker and Bdalbagi (2015) and Syed Ali (2017). 
Effect of Inclusion of Moringa oliefera Leaf Meal on the Growth Performance, Nutrient Digestibility and Carcass...

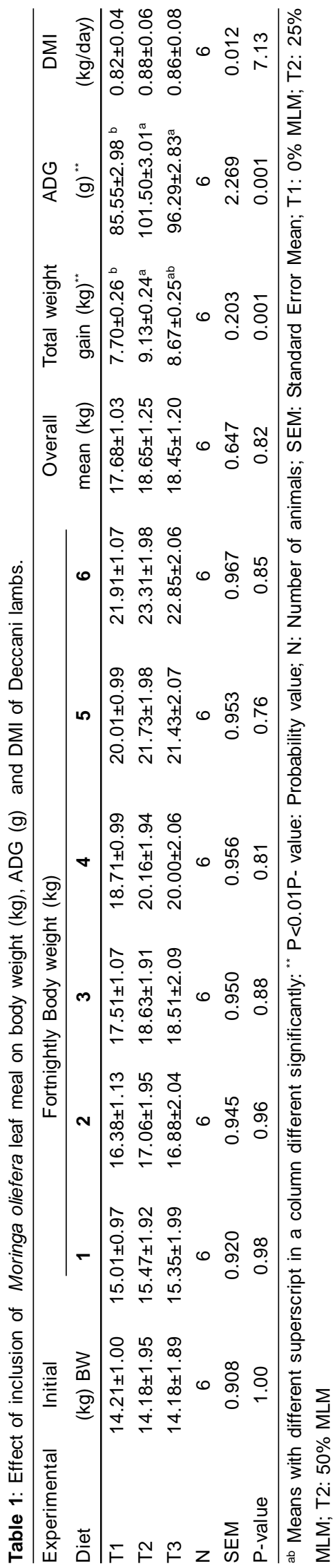

\section{Average daily gain}

The T2 group lambs fed with 25\% MLM-based concentrate mixture had significantly $(P<0.01)$ higher ADG than T1 group lambs. However, there was no significant difference between T2 and T3 groups. Higher digestibility of nutrients with efficient utilization of absorbed nitrogen might be the reason for increased ADG in supplemented lambs. The present findings are in concurrence with findings of Sultana et al. (2015) and Bebekar and Bdalbagi (2015), Damor et al. (2017), in goats when fed with Moringa oleifera leaves. Syed Ali (2017), Bhavana et al. (2018) reported a non-significant difference in average daily body weight gain among the treatment groups.

\section{Dry matter intake}

The average daily dry matter intake (kg/day) in Deccani growing lambs fed with experimental diets were numerically higher in the T2 diet (Table 2). The values recorded for average DMI per $100 \mathrm{~kg}$ body weight were not significantly different among three different diets. The daily average dry matter intake (DMI) per $100 \mathrm{~kg}$ body weight was comparatively higher in Deccani lambs fed with T2 and T3 diets.

The non-significant increase in the DMI among the experimental groups could be due to the lower fiber content of the Moringa leaves thereby enhancing the palatability and digestibility. The observations made in the present study are concurrent with Damor et al. (2017) and Bhavana et al. (2018) who reported non-significant differences in DM intake in animals supplemented with Moringa oleifera leaves. In contrast to the present findings, Sarwatt, et al. (2002), Sultana et al. (2015) and Babeker and Bdalbagi (2015) reported a significant increase in dry matter intake on Moringa leaves supplementation.

\section{Feed conversion ratio}

The FCR in the T1 diet is higher than T2 and T3 diets and there was no significant difference in FCR among the lambs fed on three experimental diets. However, the lowest FCR found in the Moringa included groups. The present study results are in agreement with the findings of Bhalerao (2018) who reported the lower feed conversion ratio in goats fed with different levels of Moringa leaves.

\section{Nutrient digestibility}

The average dry matter digestibility coefficient is presented in Table 2. The dry matter digestibility coefficient (\%) was non-significantly higher in T2 and T3 than in T1 group lambs. Higher digestibility of Moringa supplemented diets could be due to low structural carbohydrates and good quality protein. The results obtained in the present study are corroborated with the finding of Manh et al. (2005) and Sultana et al. (2015) who observed in the concentrate mixture the DM digestibility did not significant with increased Moringa levels.

The organic matter digestibility coefficients (\%) were non-significantly $(P>0.05)$ higher in the T2 and T3 treatment groups when compared with the control (T1) group. The 
obtained value is in agreement with the finding of Asaolu et al. (2011), Tona et al. (2014) and Sultana et al. (2015) reported the non-significant effect of Moringa leaves inclusions in dietary treatments.

Among the Moringa leaf meal supplemented lambs, T2 lambs showed a relatively higher CP digestibility coefficient than T3. Higher crude protein digestibility coefficient (\%) in Moringa supplemented groups could be due to the presence of high-quality protein in the leaves. Similar results were reported by and Oyedem et al. (2016) and Syed Ali (2017) and Soby et al. (2015). The present results are in disagreement with the observations of Tona et al. (2014), Fadiyimu et al. (2016).

Relatively higher CF digestibility was observed in the Moringa leaf meal supplemented group (T2 and T3) compared to the control group (T1) lambs (Table 2). However, the differences were not significant. The higher CF digestibility in T2 and T3 equally suggests an increase in the activities of fibrolytic bacteria in the rumen probably as a result of the availability of essential nutrients especially protein, energy and minerals in balanced proportions. The obtained values are in line with the finding of Soby et al. (2015), Sultana et al. (2015), Oyedele et al. (2016) and Syed Ali (2107). While Fadiyimu et al. (2010), Tona et al. (2014) and Kholif et al. (2016) reported dissimilar results. No significant difference was found in the average ether extract digestibility coefficients among the three experimental diets. A similar finding was reported by Sultana et al. (2015) and Syed Ali (2017). The average Nitrogen free extract digestibility was significantly $(\mathrm{P}<0.05)$ higher in the $\mathrm{T} 2$ and T3 treatment groups when compared to the control (T1) group. T2 group had significant difference with T3 and T1 groups.

The higher NFE digestibility in T2 and T3 could be due to the supply of essential nutrients especially protein, energy and minerals in balanced proportions through Moringa leaf meal. Similar findings are reported by Akinyemi et al. (2010) and Syed Ali (2017) when sheep and goats respectively fed with Moringa oleifera as supplements to Panicum maximum and Cottonseed cake, respectively. Soby et al. (2015) reported dissimilar results when different levels of Moringa leaves fed to fattening lambs.

The observed neutral detergent fibre digestibility was non-significantly $(P>0.05)$ higher in T2 and T3 groups than in T1 group lambs. The higher NDF digestibility in T2 and T3 equally suggests an increase in the activities of fibrolytic bacteria in the rumen probably as a result of the supply of essential nutrients through Moringa leaf meal. Similar findings were reported by Akinyemi et al. (2010) who reported higher value for NDF digestibility when animals fed with Moringa oleifera leaves.

Acid detergent fibre digestibility was non-significantly higher in T2 and T3 groups compared to T1 group lambs. It could be due to the higher rumen microbial activity and availability of digestible cellulose from ADF of Moringa foliage to the lambs. The values obtained for ADF digestibility are similar to those recorded by Manh et al. (2005) and Akinyemi et al. (2010) reported higher values for ADF digestibility when increasing the inclusion level of Moringa oleifera. In contrast to the present findings, Mahmoud (2013) reported a significant $(P<0.05)$ difference between the Moringa supplement groups in growing lambs.

Table 2: Effect of inclusion of Moringa oliefera leaf meal on nutrient digestibility of Deccani lambs.

\begin{tabular}{lcccccccc}
\hline Treatment & $\begin{array}{c}\text { Dry } \\
\text { matter }\end{array}$ & $\begin{array}{c}\text { Organic } \\
\text { matter }\end{array}$ & $\begin{array}{c}\text { Crude } \\
\text { protein }\end{array}$ & $\begin{array}{c}\text { Crude } \\
\text { fibre }\end{array}$ & $\begin{array}{c}\text { Ether } \\
\text { extract }\end{array}$ & $\begin{array}{c}\text { Nitrogen } \\
\text { free } \\
\text { extract* }\end{array}$ & $\begin{array}{c}\text { Neutral } \\
\text { detergent } \\
\text { fibre }\end{array}$ & $\begin{array}{c}\text { Acid } \\
\text { detergent } \\
\text { fibre }\end{array}$ \\
\hline T1 & $64.81 \pm 0.93$ & $67.21 \pm 1.40$ & $69.64 \pm 2.35$ & $62.90 \pm 0.61$ & $78.89 \pm 3.33$ & $70.10 \pm 1.36^{b}$ & $69.78 \pm 0.52$ & $62.62 \pm 1.60$ \\
T2 & $66.21 \pm 0.69$ & $68.60 \pm 0.89$ & $71.40 \pm 2.37$ & $63.14 \pm 0.71$ & $80.70 \pm 2.97$ & $75.23 \pm 1.24^{\mathrm{a}}$ & $71.82 \pm 0.88$ & $66.38 \pm 1.51$ \\
$\mathrm{~T} 3$ & $65.14 \pm 0.45$ & $67.86 \pm 0.80$ & $70.93 \pm 2.15$ & $62.95 \pm 0.81$ & $79.72 \pm 3.25$ & $72.88 \pm 1.12^{\mathrm{ab}}$ & $70.84 \pm 0.42$ & $65.32 \pm 1.85$ \\
$\mathrm{~N}$ & 6 & 6 & 6 & 6 & 6 & 6 & 6 & 6 \\
$\mathrm{SEM}$ & 0.406 & 0.593 & 1.256 & 0.536 & 1.747 & 0.844 & 0.401 & 0.977 \\
$\mathrm{P}$ & 0.38 & 0.66 & 0.86 & 0.66 & 0.92 & 0.03 & 0.11 & 0.29 \\
\hline
\end{tabular}

ab Means with different superscript in a column different significantly: " $\mathrm{P}<0.05 \mathrm{P}$ - value: Probability value.

Table 3: Effect of feeding Moringa based diets on carcass characteristics of Deccani lambs under intensive system.

\begin{tabular}{|c|c|c|c|c|c|c|c|}
\hline Treatments & $\begin{array}{l}\text { Pre-slaughter } \\
\text { live weight } \\
(\mathrm{kg})\end{array}$ & $\begin{array}{c}\text { Empty live } \\
\text { weight } \\
(\mathrm{kg})\end{array}$ & $\begin{array}{c}\text { Hot carcass } \\
\text { weight } \\
(\mathrm{kg})\end{array}$ & $\begin{array}{c}\text { Dressing } \\
\% \\
\text { (PSW) }\end{array}$ & $\begin{array}{c}\text { Dressing } \\
\% \\
(E L W)\end{array}$ & $\begin{array}{c}\text { Edible } \\
\text { offal } \\
(\mathrm{kg})\end{array}$ & $\begin{array}{c}\text { Non-edible } \\
\text { offal } \\
(\mathrm{kg})\end{array}$ \\
\hline $\mathrm{T} 1$ & $21.33 \pm 7.41$ & $17.33 \pm 0.49$ & $10.30 \pm 0.52$ & $48.75 \pm 0.69$ & $59.34 \pm 1.38$ & $0.57 \pm 0.02$ & $5.90 \pm 0.63$ \\
\hline T2 & $22.30 \pm 3.41$ & $17.46 \pm 1.96$ & $10.70 \pm 1.95$ & $47.55 \pm 2.06$ & $63.60 \pm 4.48$ & $0.64 \pm 0.14$ & $5.51 \pm 0.17$ \\
\hline T3 & $26.16 \pm 7.41$ & $22.50 \pm 1.77$ & $14.50 \pm 1.69$ & $48.10 \pm 2.21$ & $61.80 \pm 3.23$ & $0.70 \pm 0.12$ & $8.18 \pm 0.51$ \\
\hline $\mathbf{N}$ & 3 & 3 & 3 & 3 & 3 & 3 & 3 \\
\hline SEM & 1.566 & 0.936 & 0.883 & 1.764 & 0.997 & 0.059 & 0.298 \\
\hline $\mathbf{P}$ & 0.47 & 0.32 & 0.47 & 0.66 & 0.53 & 0.73 & 0.28 \\
\hline
\end{tabular}


Effect of Inclusion of Moringa Oliefera Leaf Meal on the Growth Performance, Nutrient Digestibility and Carcass...

\section{Carcass characteristics}

T3 group had statistically non-significant $(P>0.05)$ higher pre-slaughter, empty live and hot carcass weights than T2 and T1 groups (Table 3). There was a non-significant difference $(P>0.05)$ in dressing percentage on pre-slaughter and empty live weights basis in all three treatment groups. However, the T2 group had a numerically higher dressing percentage $(63.3 \pm 4.48)$ on empty live weight compared to the T1 (59.34 \pm 1.38$)$ and T3 (61.8 \pm 3.23$)$ group. Lower gut fill due to higher digestibility and higher empty live and hot carcass weights due to better feed efficiency with Moringabased rations in T2 and T3 resulted in better productivity.

A non-significant difference was observed among the treatment groups for the weight of liver, kidney, heart and testis. The weight of the head, leg, skin, blood, lung, stomach was also non-significant among the treatment groups. However, relatively higher edible and non-edible offal weights were observed with Moringa-based rations supplemented lambs (T2 and T3). This might be due to efficient digestion and absorption of nutrients leading to better growth and development of the gut (Meel, et al., 2021).

A similar result was reported for hot carcass weight and edible organ weights by Moyo et al. (2013) when crossbred Xhosa lop-eared goats were fed with Moringa oleifera leaves. In the case of dressing percentage, a lower dressing percentage was reported by Moyo et al. (2013). A similar result was reported by Kochewad et al. (2018) in Decani lambs when reared in intensive farming systems.

\section{CONCLUSION}

Moringa oleifera is a very good source of protein, antioxidants, minerals and vitamins. It could be used as an alternative feed resource in the diet of Deccani lambs. From the present investigation, it is evident that Moringa oleifera could be included in the diet of Deccani lambs at $50 \%$ level for better performance without any adverse effects.

\section{Conflict of interest}

The authors declares that they have no conflict of interest.

\section{REFERENCES}

A.O.A.C. (2005). Official Methods of Analysis. 18 Ed. Association of Official Analytical Chemist, Benjamin Franklin Station, Washington, DC.

Asaolu, V.O., Binumote, R.T., Akinlade, J.A. Oyelami, O.S. and Klapo, K.O. (2011). Utilization of Moringa oleifera fodder combination with Leucaena leucocephala (LEU) and Gliricidia sepium (GLI) fodder by West Affrican dwaef goats (WAD). International of Agricultural Research. 6(8): 607-619.

Aharwal, B., Biswajit Roy, Lakhani, G.P., Bhogel, R.P.S., Kiranpal Singh Saini and Ayush Yadav. (2018). Effect of Moringa oleifera Leaf mealon feed intake and growth performance of Murrha Buffalo calves. Indian Journal of Current Microbiology and Applied Science. 7(9): 1960-1973.
Babeker, E.A. and Bdalbagi, Y.M.A. (2015). Effects of feeding different levels of Moringa oleifera leaves on the performance, haematological, biochemical and some physiological parameters of Sudan Nubian goats on three different levels of Moringa oleifera. Journal of Animal and Feed Research. 5(2): 50-61.

Bhalerao, S.M. (2018). Effect of supplementation of Moringa oleifera leaf meal on the performance of growing sheep. M.V.Sc thesis submitted to MAFSU, Nagpur.

Damor, S.V., Pawar, M.M., Ankuya, K.J., Gami, Y.M., Srivastava, A.K., Chauhan, H.D. and Chaudhary, K.R. (2017). Effect of feeding different levels of Moringa (Moringa oleifera) leaves on growth performance of Mehsana goat kids. Significance. 10(18): 3190-3193.

Fadiyimu, J.A., Alokan, A.N., Fajemisin and Onibi, G.E. (2016). Feed Intake, Growth Performance and Carcass Characteristics of West African Dwarf Sheep Fed Moringa oleifera, Gliricidia sepium or Cassava Fodder as Supplements to Panicum maximum. Journal of Experimental Agriculture International. 14(4): 2231-0606.

Gebregiorgis, F., Negesse. (2011). Feed intake and utilization in sheep fed graded leaves of dried Moringa (Moringa stenopetala) leaf supplemented to Rhodes grass hay. Tropical Animal Health Production. 44(3): 51-517.

Gerrand, F. (1964). Meat Technology. $3^{\text {rd }}$ edition Leonard Hell Limited, London.

Kholif, A.E., Gouda, G.A., Morsy, T.A., Salem, A.Z.M., Lopez, S. and Kholif, A.M. (2015). Moringa oleifera leaf meal as a protein source in lactating goat's diets: Feed intake, digestibility, ruminal fermentation, milk yield and composition and its fatty acids profile. Small Ruminant Research. 129: 129-137.

Kochewad, S.A., Raghunandan, T., Kapa Sargan Rao, Kondal Reddy, Nalilni, N. and Ramana, D.B.V. (2018). Productive performance, body condition score and carcass characteristics of Deccani lambs reared under different farming systems. Indian Journal of Animal Research. 52(3): 2018.

Mahmoud, A.E.M. (2013). Effect of feeding on Moringa oleifera stems on productive performance of growing lambs. Egyptian Journal Nutrition and Feeds.16 (2): 281-292.

Manh, L.H., Dung N.N.X. and Ngoi, T.P. (2005). Introduction and evaluation of Moringa oleifera for biomass production and as feed for goats in the Mekong Delta. Livestock Research for Rural Development. 17(9): 4.

Makkar, H.P.S and Becker, K. (1997). Nutrients and anti-quality factors in different morphological parts of the Moringa oleifera tree. The Journal Agricultural Science. 128: 311-332.

Meel, M.S., Sharma, T., Monika Joshi, M.L., Gurjar, S.K., Sharma, Mamta Kuma. (2021). Effect of feeding Moringa oleifera leaf meal with multienzyme on performance, carcass characteristics and economics of production of broiler chicks. Asian Journal of Dairy and Food Research. 40(1): 118-122.

Moyo, B., Julius, P.M. and Muchenje, V. (2013). Effects of supplementing cross-bred Xhosa lop eared goats with Moringa oleifera Lam. on helminth load and corresponding body condition score, packed cell volume. African Journal of Agricultural Research. 8(43): 5327-5335. 
Moyo, B., Patrick, J.M. and Mu chenje, V. (2012). Effect of supplementing crossbred Xhosa lop- eared goat castrates with Moringa oleifera leaves on growth performance, carcass and noncarcass characteristics. Tropical Animal Health Production. 44: 801- 809.

Oyedele, O.J., Asaolu, V.O. and Odeyinka, S.M. (2016). Studied nutrient digestibility and growth performance of West African dwarf (wad) goats fed foliage combinations of Moringa oleifera and Gliricidia sepium with equal proportions of a low-cost concentrate. Journal of Natural Sciences Research. 6: 18.

Ravani, A., Prasad, R.V., Gajera, R.R. and Joshi, D.C. (2017). Potentiality of moringa oleifera for food and nutritional security - A review. Agricultural Reviews. (38): 228-232.

Sarwatt, S.V., Kapange, S. and Kakengi, A.M.V. (2002). Substituting sunflower seed-cake with Moringa oleifera leaves as a supplemental goat feed in Tanzania. Agroforestry Systems. 56: 241-247.

Snedecor, G.W. and Cochran, W.G. (1994). Statistical methods. $8^{\text {th }}$ Edn, lowa State University Press, Ames, lowa, USA50010.

Soby, M., Allam, G.E., Aboul-Fotouh, G.M., El-Garhy and Ola Gamal. (2015). Use of moringa leaves (Moringa oleifera) in fattening lambs rations. Egyptian Journal of Nutrition and Feeds. 18(2): 11-17.
Sultana, N., Alimon, A.R., Huque, K.S., Baba, M. and Hossain, J. (2015). Evaluation of Moringa foliage (Moringa oleifera) as Goat Feed Iranian. Journal of Applied Animal Science. 5(4): 8871.

Syed Ali (2017). Growth Performance of Goats Feed Moringa oleifera Leaf Meal Incorporates in Concentrated Mixture M.V.Sc. Thesis submitted to MAFSU, Nagpur.

Tona, G.O., Ogunbosoye, D.O. and Bakare, B.A. (2014). Growth performance and nutrient digestibility of West African Dwarf goats fed graded levels of Moringa oleifera leaf meal. International Journal of Current Microbiology and Applied Sciences. 3 (8): 99-106.

Yousuf, A.O., Malamb, V. and Iposu, S.O. (2018). A nutritional and economic evaluation of Moringa oleifera leaf meal as dietary supplement in West African Dwarf goats. South African Journal of Animal Sciences. 48(1).

Van Soest, P.J., Robertson, J.B. and Lewis, B.A. (1991). Methods of dietary fiber, neutral detergent fiber and non-starch polysaccharides in relation to animal nutrition. Journal of Dairy Science. 74: 3583-3597. 